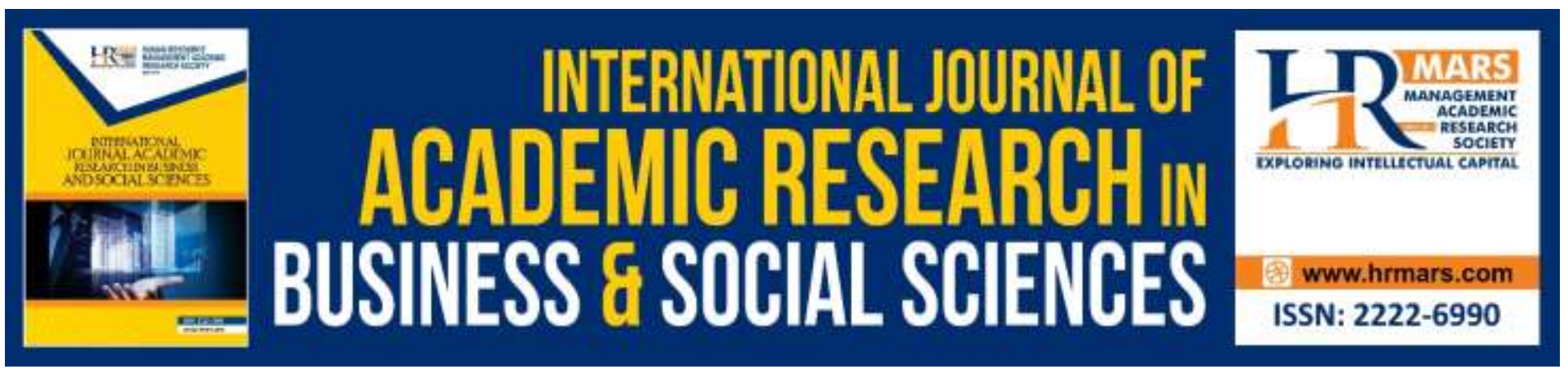

\title{
Human Governance: How Ethical Behaviour of Accountants can be Improved
}

\author{
Haslinah Muhamad, Arfah Salleh, Nor Aziah Abu Kasim \& Susela Devi K. \\ Suppiah
}

To Link this Article: http://dx.doi.org/10.6007/IJARBSS/v9-i7/6129

DOI: $10.6007 /$ IJARBSS/v9-i7/6129

Received: 13 May 2019, Revised: 15 June 2019, Accepted: 01 July 2019

Published Online: 23 July 2019

In-Text Citation: (Muhamad, Salleh, Kasim, \& Suppiah, 2019)

To Cite this Article: Muhamad, H., Salleh, A., Kasim, N. A. A., \& Suppiah, S. D. K. (2019). Human Governance: How Ethical Behaviour of Accountants can be Improved. International Journal of Academic Research in Business and Social Sciences, 9(7), 370-385.

\section{Copyright: (C) 2019 The Author(s)}

Published by Human Resource Management Academic Research Society (www.hrmars.com)

This article is published under the Creative Commons Attribution (CC BY 4.0) license. Anyone may reproduce, distribute, translate and create derivative works of this article (for both commercial and non-commercial purposes), subject to full attribution to the original publication and authors. The full terms of this license may be seen

at: http://creativecommons.org/licences/by/4.0/legalcode

Vol. 9, No. 7, 2019, Pg. 370 - 385

http://hrmars.com/index.php/pages/detail/IJARBSS

JOURNAL HOMEPAGE

Full Terms \& Conditions of access and use can be found at http://hrmars.com/index.php/pages/detail/publication-ethics 


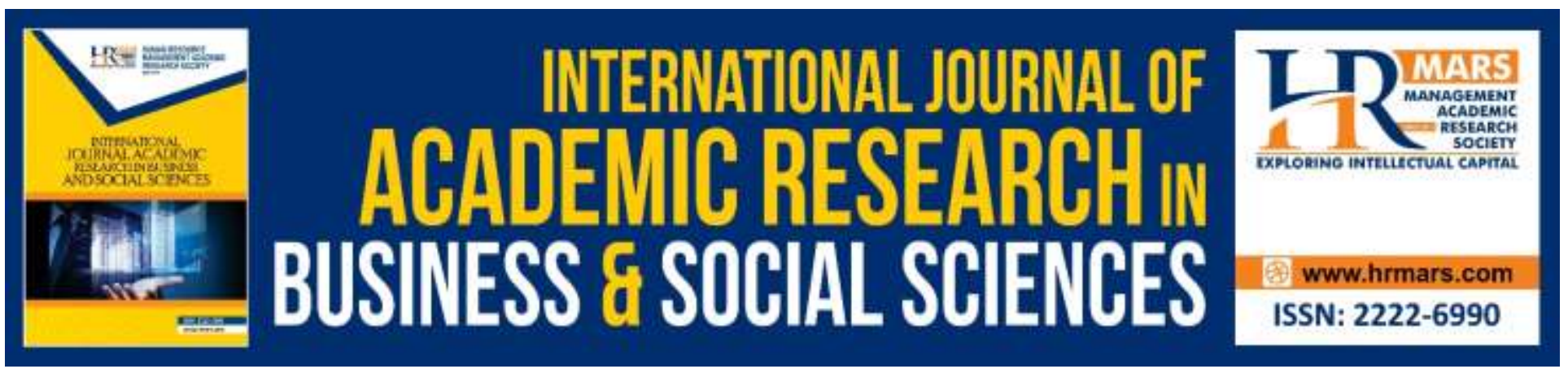

\title{
Human Governance: How Ethical Behaviour of Accountants can be Improved
}

\section{Haslinah Muhamad $^{1 *}$, Arfah Salleh², Nor Aziah Abu Kasim ${ }^{3}$ \& Susela Devi K. Suppiah ${ }^{4}$}

${ }^{1,3}$ Department of Accounting and Finance, Faculty of Economics and Management, Universiti Putra

Malaysia, Serdang, Selangor, Malaysia

${ }^{2}$ Human Governance Institute Inc. (HGII), 22nd Floor, Menara Safuan, 80 Jalan Ampang, 50450 Kuala Lumpur, Wilayah Persekutuan, Malaysia

${ }^{4}$ Department of Accounting, Sunway University Business School (SUBS), No. 5, Jalan Universiti,

Bandar Sunway,47500 Selangor Darul Ehsan, Malaysia

\begin{abstract}
This article reports the development of philosophy underpinning ethics education especially in the accounting field from the oldest systematic philosophers in western culture as a starting point to the current situation of teaching ethics and the suggestion of new direction by the installation of the concept of human governance. Compare to the oldest era, education in the era of industrial revolution emphasises on the development of technical skills and producing specialists and scientists. Postmodernism scholars find that schools in this era are not teaching humanities in ways conducive to cognitive development or respect for traditional knowledge and values. Consequently, critiques on this kind of education started emphasis in the late eighties and nineties. However, only after the Enron scandal, attention is given to develop long-term strategy to tackle the issue of unethical behaviour among accountants through stringent rules and regulation, code of ethics, ethics education and research. The need to adopt a new philosophy as a supplement in teaching ethics has arisen. This paper proposed to introduce the concept of human governance into accounting ethics education especially at university level. Additionally, this paper had also provided the overview of the concept of human governance.
\end{abstract}

Keywords: Ethics, Accounting Education, Human Governance

\section{Introduction}

Idealism philosophers in the western culture (dating back to at least Plato in the ancient Greece era) generally agreed that education should not only stress on the development of cognitive part (the mind) but also should focus on affective parts which are more lasting value (Ozmon and Craver, 2008). Additionally, idealistic educators aim to develop individual characters where education is not just about developing a literate and knowledgeable person, but also to develop a good person. However, 
INTERNATIONAL JOURNAL OF ACADEMIC RESEARCH IN BUSINESS AND SOCIAL SCIENCES Vol. 9, No. 7, July, 2019, E-ISSN: 2222-6990 @ 2019 HRMARS

several factors such as industrialisation and technological advancement, as well as the development in science have brought fundamental challenges to the idealism school of thoughts.

In comparison to idealism, the realism philosophies placed more emphasis on the material world (Ozmon and Craver, 2008; Visher, 1997). Shaped by Classical-Newtonian Science, secular realism maintains that essential ideas and facts can be best learned only by studying the material world. Secular realists promote a study of science and the scientific method. The empirical movement by secular realists, which included Bacon and Locke, had promoted the idea of verification. This bring forth that ideas that cannot be proven through scientific experiments can only be considered as hypotheses. Realism displays a fact-based approach to knowledge, where facts constitute observable and verifiable data. Another assumption of the realists is that anything that exists in quantities can be measured. What one discovered by statistical research is scientific and factual; this in turn, leads researchers in both science and social science disciplines to believe that these statistical findings reveal the truth.

To meet the demands of industrial and technological age, realists argued that education should develop technical skills and produce specialists and scientists. Although they are not opposed to education in humanities, they find that schools are not teaching humanities in ways conducive to cognitive development or respect for traditional knowledge and values (Ozmon and Craver, 2008). This lack of cognitive development or respect for traditional knowledge and values is continuously debated in education circles, particularly when dealing with higher education (Ozmon and Craver, 2008). Thus, postmodern theories of education are critical to this type of education.

Postmodernism stresses that ethics must be of a central concern to develop students' identities that enable them to stand up against inequality and violation of basic human rights (Ozmon and Craver, 2008). In addition, some postmodernists do believe that students need to become educated in social studies supplemented by technical knowledge before they could become effective moral agents. In fact, Herbart (1776-1841), a German philosopher, psychologist, and founder of pedagogy as an academic discipline, views moral as the supreme purpose of education (Hilgenheger, 1994). Additionally, recent modern-day educationist philosophers such as Palmer (2007), Hansen (2001) and Al-Attas (1990) also emphasised the need to re-actualise education on the moral purpose as its aspects in education appear to have been side lined over time.

It is encouraging and heartening to learn that ethics remains a significant agenda in accounting education. What is available and abundant in literature is the highlight on the failure of the accounting education to inculcate ethical behaviour among accountants (Bunker and Casey, 2012; Salleh and Ahmad, 2012; Amlie, 2010; McPhail, 2006; Gioia, 2002; Plimmer, 2002; Gray et al., 1994), however, to find a solution that addresses the ineffective ethics education in accounting remains pressing. Therefore, embedding human governance in the curriculum of Institute of Higher Learning whether in Malaysia or abroad presents a prospect that should not be dismissed especially when more cases of fraudulent accounting practices kept surfacing. 
Human governance is founded upon the premise of human as being spiritual, embodied in a bio-body suit unlike earlier human-as-machine axiom upon which most educational, management and social theories are founded upon (Salleh and Ahmad, 2008). Accountants who embrace human governance accept their interconnectedness with other people and the planet. Hence, these accountants perform their duties and responsibilities governed by their high level of conscience and consciousness of societal well-being knowing that their actions will affect others. Externally imposed law, rules and regulation for ethical conduct become additional guidelines to their behaviour, which is already internally governed.

While the need to focus on human governance has been accepted by the Malaysian accounting regulatory body, within accounting education, there is yet any documentation that stresses the necessity to incorporate human governance into the accounting curriculum. In fact the empirical work on this concept is still limited.

\section{Ethics in Accounting Education}

Accounting and moral behaviour are synonymous because accountants play a role as the custodian of public trust (Salleh and Ahmad, 2010; Dellaportas et al., 2005). Even prior to Enron, the famous accounting scandal, works such as that conducted by McPhail (2001), Geary and Sims (1994), and Loeb (1988) have emphasised the need to enrich ethics in accounting education by inculcating morality or values to improve the moral behaviour and credibility among accountants. However, it was only in response to the Enron scandal that IFAC began to include education as a long-term strategy to tackle the issue of unethical behaviour among accountants through the issuance of the relevant International Education Standards (IES). The attributes of ethical values required by professional accountants are contained in the specially drawn IES 4 (effective January, 2006) on Professional Values, Ethics and Attitudes. In addition, IFAC had issued the International Education Practice Statement (IEPS) 1 in 2006 to provide guidance on the implementation of IES 4 and the development of professional values, ethics and attitudes in accordance to that standard.

Later, IFAC released the Framework for International Education Standards for Professional Accountants (2008), which outlines that the objective of accounting education is to develop competent professional accountants. To demonstrate competence in their role, a professional accountant must possess the essential knowledge and skills including values, ethics, and attitudes. Education, according to the IFAC, is a systematic process aimed at acquiring and developing knowledge, skills, and other capabilities within individuals; a process that is typically but not exclusively conducted in academic environments. The implication of this pronouncement is that all member bodies are obliged to comply with the International Education Standards for Professional Accountants and other IAESB guidance including the Framework of International Education Standards for Professional Accountants. What can be observed from the series of pronouncements made by IFAC is the importance of education as a tool to inculcate ethics.

Consistent with the philosophy of IFAC on the role of accounting education in inculcating ethics, the Ministry of Higher Education of Malaysia in 2006 revised the Reassessment Report on Accounting 
INTERNATIONAL JOURNAL OF ACADEMIC RESEARCH IN BUSINESS AND SOCIAL SCIENCES Vol. 9, No. 7, July, 2019, E-ISSN: 2222-6990 @ 2019 HRMARS

Programme offered by Malaysian Public Universities (Hala Tuju 2) to require these educational institutions to incorporate 12 learning outcomes in their respective accounting degree curriculum, one of which is a demonstration of students' ethical behaviour.

Due to studies that show accounting education being largely guilty of failing to develop students' intellectual and moral abilities abounds (see Amernic and Craig, 2004; Swanson and Frederick, 2003; McPhail, 2001), scholars continue to argue for the need to re-examine the type of educational system that produces accounting professionals who, consciously or otherwise, appear to act unethically (Boyce, 2008; Low, et al., 2008). Even after the pronouncement of the relevant educational standards on ethics by IFAC, Low et al., (2008) argued that the lack of morals in educated people has contributed to the financial reporting scandals and corporate frauds.

There is an extensive research carried out on the extent of ethics education in accounting curriculum emanated from developed countries particularly in the USA, UK and Australia. Evidence from USA suggests that there is a decline courses of ethics or embedded ethics particularly in accounting education (Dellaportas, Kanapathippillah, Khan, \& Leung, 2014). The encouragement also decrease by the flexibility of the Association to Advance Collegiate Schools of Business (AACSB) standards, which requires less stand-alone ethics courses offered starting from 2007 (Blanthorne, Kovar, \& Fisher, 2007).

In the UK, the extension of ethics appears to be embedded in existing courses, typically financial accounting and auditing (Dellaportas, Kanapathippillah, Khan, and Leung, 2014; Ghaffari, Kyriacou, and Brennan, 2008). Similar to the USA, corporate financial scandals appear to be a major driver for prompting the development of accounting ethics education offered by universities in UK (Dellaportas, Kanapathippillah, Khan, \& Leung, 2014).

Meanwhile in Australia and New Zealand, only $4 \%$ of institutions offer ethics as a stand-alone course in undergraduate accounting programmes and none at graduate level (Dellaportas, Kanapathippillah, Khan, \& Leung, 2014). 'Auditing' and 'Accounting Theory' represent a popular course for the integration of ethics. There are an argument that undergraduate students should have at least one stand-alone, well-organised, reasonable long course in accounting ethics to be able to grasp the complexity of analysing and solving ethical problems (Gray, Bebbington, \& McPhail, 1994). In addition, a stand-alone ethics course show the universities' commitment to the importance of ethics in education as a centre of discussion rather than a supplementary subject (Fisher, Swanson, and J.Schmidt, 2011; Fisher and Swanson, 2005). However, there are limitations for a discrete or standalone course of ethics. The material in a discrete course may be over theoretical or over simplistic, which may adequate the relevance of the topic to accounting students (Piper, Gentile, \& Parks, 1993). Similarly, entry-level students with a minimal knowledge of the functional aspect of business and accounting are less likely to effectively deal with the materials in an ethics course. Consequently, any expectation on raising the ethical sensitivity of entry-level students will be unrealistic (McDonald \& Donleavy, 1995). 
INTERNATIONAL JOURNAL OF ACADEMIC RESEARCH IN BUSINESS AND SOCIAL SCIENCES

Vol. 9, No. 7, July, 2019, E-ISSN: 2222-6990 @ 2019 HRMARS

\section{New Directions for Ethics Education in Accounting}

In dealing with unethical behaviour and reduced credibility of the accounting profession, McPhail, (2001) argued that the starting place for developing ethical or moral competency should be through accounting ethics education. The High Level Group on the Modernisation of Higher Education, (2013) recommended that institutions of higher learning and professional educators should work together to improve the quality of the profession. Furthermore, Armstrong (1993) argued that the positive effect of ethics education is on the quality of students' moral development.

Several scholars argued that, fixed legalistic mind-set is one of inadequacies of ethics in accounting education due the current practice of implementing rule-based education (Kaptein and Schwartz, 2008; Helin and Sandstro“m, 2007). Arjoon (2005) claimed that legal compliance mechanisms are insufficient, which may not address the real and fundamental issues inspiring ethical behaviour. The insufficiency of code of ethics as a legal compliance mechanism in influencing ethical behaviour has also been proven in various studies such as that conducted by Kapteinand Schwartz (2008), Healy and Iles (2002), Marnburg (2000), Clark and Leonard (1998), and Brooks (1989).

In Malaysia, Mohammad et al. (2002) concluded that the codes of ethics hold only little or no significant influence on the behaviour of accountants because of several reason such as lack of exposure to ethics and ethical issues, vagueness of the codes, absence of actual guidelines on ways to solve conflicts, and the absence of legal standing to subject offenders to prosecution in the court of law. Therefore, the current practice of rules-based approach in ethics accounting education with emphasis on compliance with the laws needs to be revisited or revised. Ryack, Mastilak, Hodgdon, \& Allen, (2015) suggested that, where possible, accounting educators may wish to teach principlesbased accounting prior to rules-based accounting to mitigate any potential anchoring by students and its effect on their accounting judgment.

Due to the continuous accounting scandals and unethical behavior among accountants, there is a need to adopt principle-based corporate governance to supplement the existing rules-based structure in order to promote ethical behavior in business (Salleh and Ahmad, 2010 and 2009; Salleh and Ahmad, 2008; Arjoon, 2005). There is a proposal from practitioners in Malaysia to introduce the concept of human governance to the academic world especially at university level. If the proposal is implemented, the cooperation and support from the Ministry of Higher Education (MOHE) and educators from Malaysian Public Universities are of necessary. However, before the human governance approach can be implemented, the initiators claims that accounting educators need to shift their view towards the reality of the world phenomena (ontological assumptions) including the definition of human and ethics. In order to inculcate values among accounting students, the definition of human must first allow for consciousness and values instead of viewing human as a complicated machine. Since the concept of human governance is a new concept that differs from the traditional rules-based structure, educators' epistemological stance (concerning what constitutes acceptable knowledge) also needs to be examined. However, the respond from educators and, and their level of acceptance on the human governance concept are still perplexing. 


\section{Human Governance}

Human governance refers to being human. Being human means being guided by a common set of principles inherent in every human being (Salleh and Ahmad, 2010). According to Salleh and Ahmad (2010), to guidance in our action, we must first identify our self by answering the question "who am I?" What is the purpose of our life? What is real and what is not and how can we know what is real? The second has to do with our relationship to the reality we discerned, which can be variously formulated as "How should we relate to others?" as well as "How should we govern ourselves?" From time immemorial, cultures around the world attempted to identify the qualities of what it means for a human being to do the right thing. It is beyond being moral and ethical, which is being fundamentally human. It is about who we are, the reason we were created and what we need to become.

\section{Definition of Human}

The definition of "human" by Human governance was influenced by several scholar as well as religion. Among the scholar is a Scottish physician named William Stodardd (1985). According to Stodardd, man (human being) is constituted by the ternary of spirit, soul, and body (spiritus, anima, and corpus).

Stodardd, (1985) used the terms as shown in Table 1 to describe human in several languages with similar meaning.

Table 1: Human element

\begin{tabular}{|c|c|c|c|}
\hline English & Latin & Greek & Arabic \\
\hline $\begin{array}{c}\text { Spirit } \\
\text { (Intellect) }\end{array}$ & $\begin{array}{c}\text { Spiritus } \\
\text { (Intellectus) }\end{array}$ & $\begin{array}{c}\text { Pneuma } \\
\text { (Nous) }\end{array}$ & Ruh ('Aql) \\
\hline Soul & anima & psyche & nafs \\
\hline Body & corpus & soma & jism \\
\hline & & & \\
\hline
\end{tabular}

Source: William Stodardd (1985)

Stodardd (1985) see "intellectual" as a highest part of human being which is "above" the soul, the mind or reason is a content of the soul similar to other human faculties such as will, affect or sentiment, imagination, and memory (pg. 3). The spiritual or intellectual faculty can be categorised as "angelic" due to its high level. The operation of intellect is referred to as "intellectual intuition" or "intellection". However, there is no absolute barrier between intellect and mind. The only difference is that intellect may be compared to the centre of a circle, while the mind to the circumference. Figuratively speaking, the Greek or older era philosophers were concerned with the "centre" or, to put it even more accurately, the Transcendent symbolised by the axis running vertically through it. The Transcendent element-man's infinitely precious link with the higher levels of Reality-is accessible only through faith, the voice of conscience, or what might be called Platonic intuition or "intellection" (Stodardd, 1985). 
Being a human is insufficient if one does not behave with a "conscience". Having a conscience distinguishes us as the highest form of life on this planet, with the ability to consider what is best for the Common Good, being trustees of life as we know it (Salleh \& Ahmad, A scientific worldview of accounting ethics and governance education: The right footing of International Education Standard 4,2012 ). Common qualities such as honesty, integrity, respect, trust and excellence, which are collectively known as virtues, are recognised in every society. Besides, these qualities lead the development and survival of every culture. Its success has shown to cause civilisations to flourish whereas its neglect causes eventual decay. (Salleh \& Ahmad, 2010)

Similarly, organisations and businesses follow the same principles. We have seen corporations around emphasis on the interest of maximising profit. Meanwhile, the communities, shareholders, and employees have become the fallen victim towards greedy and selfish executives from major corporate scandals such as Enron, Arthur Andersen. One of the examples of such phenomenon is the financial crisis in 2008, where we are still recovering from stems from such greed over a sustained period. Business schools students were taught to profit and grow without constraints and without caring about what happens to the rest of society and community, which further resulted in such inhuman executives. Therefore, we need to address the issue of integrity in the stewardship of corporations. However, corporate players need to re-equip themselves with the right knowledge for transformation to take place. This means that we need to move to the cause of accounting failures, addressing the individuals who somehow manifest as if they do not want to be accountable. Universities in general and business school should also emphasize to nurture the ability of utilising conscience to guide the future managers and leaders and how it may be applied to every subject taught. This is how the presence of human governance could help corporations to make decisions that will benefit the society.

\section{Human governance views of ethics}

In religion perspective, the concept of human governance is parallel with the Islamic and Christian view of ethics and affirms ethical absolutes. This paper refers to two scholars, Ibn Miskawayh and Thomas Aquinas, as the representatives of Islamic and Christian philosophy respectively, will reveal their similarities concerning on the philosophy of ethics. Ibn Miskawayh is one of the greatest Iranian Muslim philosophers in the eleventh century and his views on ethics are very famous and important. On the other hand, Thomas Aquinas is the greatest Christian theologian and philosopher in the thirteenth century and his ideas regarding ethics are famous and interesting.

Miskawayh's philosophy of ethics are based on the active struggling of the soul for its distillation. When the soul is pure and clean, it will lead to a higher rank, close to God, fellow man and the universe. It is therefore necessary to decide which soul (nafs) is fighting, and which is being fought against (a bad things) and what things they fight for (a good things). A deep disposition is a soul related state that causes the issuance of an action from a person without thinking and speculation. Miskawayh divides this disposition into two kinds; natural disposition springs and ordinary disposition. Natural disposition refer to man's nature and temper, example some people are naturally such that become angry or excited because of a minor event. On the other hand, ordinary disposition 
is created in the soul because of habit repetition. This might in the beginning be with thinking and difficulty, but it gradually becomes a deep disposition through repetition (Ibn Miskawayh, 1992 as quoted in Alavi, 2009).

Aquinas sees ethics as having two principal topics: first, the ultimate goal of human existence, and second, how to achieve (or lost) that goal ( (Kretzmann \& Stump, 1998). It is being increasingly recognized that virtue ethics is central to Aquinas's moral thought and to his consideration of the characteristic capacities and achievements of human nature (McEvoy, 2006). Aquinas maintains that happiness cannot be achieve by anything that material such as rich and famous or any endowment of soul, and any created good. For Aquinas, happy is achieving whatever we desires (Alavi, 2009). The essence of happiness consists of an act of the intellect; happiness is joy in truth (McEvoy, 2006). Aquinas argues that the often unrecognized genuine ultimate end for which human beings exist (their 'object') is God, perfect goodness personified; and perfect happiness, the ultimate end with which they may exist (their 'use' of that object), is the enjoyment of the end for which they exist. That enjoyment is fully achieved only in the beatific vision, which Aquinas conceives of as an activity.

Whereas the Bible grounds morality in God's essential character, the Qur' an teaches that God cannot ultimately be known. The good and bad action will be determined by God based on guideline provided in Al-Qur'an (Islamic book of law and regulation) and hadith (a life style of Prophet Muhammad s.a.w). Therefore, Muslims know moral goodness by God's decree. Islam and Christianity agree to some of the same moral standards although significant differences exist.

\section{Human Governance as Principle or Values-Based Approach.}

Compared to the rules-based approach, human governance is a kind of values-based approach. Individual values are shaped by principles that the individual subscribes to or educated through either informal education such as parental and family influence, life experiences, cultural and societal expectations or formal education such as schools and religious tenets (Salleh et al., 2009). When a person makes a decision, the self-chosen principles will assist that person in deciding the act is either moral or immoral and either it is ethical or unethical grounded by the above factors. Human governance promotes the inner-outer approach, which enables accountants to be internallygoverned with good values belief and to choose the best option after considering the effects of their decision making on others including the society.

Corporate governance as adopted from the Codes of Corporate Governance in many countries falls within the rules-based approach, which focuses on the essence of a corporation as an artificial person. The artificial person is an entity created by laws and given certain legal rights and duties same as human being, example corporation. Separate legal entity apply in this case. In contrast, human governance advocates that a person is viewed as a natural human who has visible and invisible parts; not as an artificial person or a complicated machine. Becker (2006) had also argued that the human being should not be treated as a machine that detaches the soul from the body. Humans are unique compared to other creatures due to their souls as good values (non-material) can only be instilled 
into the soul. Values should be taught through ethics by expressing certain fundamental beliefs and principles.

Unlike the rules-based approach that interprets ethics only as a compliance with applicable laws and regulations, the human governance approach extends the definition of ethical behaviour and integrity by focusing on values, moral and responsible behaviour. The emphasis of human governance is placed on the internal self-control of individual accountants, which encourages them to take the responsibilities associated with their position seriously and with care.

Arjoon (2005) argues that legal mechanisms tend to promote a rules-based behaviour or the stick approach, which corresponds to the letter of the law. Obeying the letter of the law means obeying the literal interpretation of the words (the "letter") of the law, but it was not necessarily the intention or the reason why the law was written. Human governance does not only concentrate on the letters of the law, but also emphasizes the spirit of the law. The spirit of the law means that a person acts according to the intention of the authors of the law rather than the literal diction of the law.

In dealing with problem-solving, human governance suggests that we should start from the root of the problem. Root cause analysis generally involves the identification of reasons to explain the cause of a problem. There are many reasons for any given problem in most cases. Correcting the root cause is imperative as it would prevent the same problem from happening again (Salleh \& Ahmad, 2008). By directing corrective measures at the root cause, it is hoped that the likelihood of a problematic recurrence will be minimised. However, it is recognised that the complete prevention of recurrence by a single intervention is impossible. To prevent or reduce unethical behaviour, we should understand the factors that motivate people to be ethical or how to make them enable to govern themselves. The differences between the rules-based approach and human governance approach are summarised in Table 2 as below: 
INTERNATIONAL JOURNAL OF ACADEMIC RESEARCH IN BUSINESS AND SOCIAL SCIENCES Vol. 9, No. 7, July, 2019, E-ISSN: 2222-6990 @ 2019 HRMARS

Table 2- Corporate Governance versus Human Governance Approach

\begin{tabular}{|c|c|c|}
\hline $\begin{array}{l}\text { Characteristics of } \\
\text { Governance } \\
\text { Structure }\end{array}$ & $\begin{array}{l}\text { Rules-based Approach } \\
\text { (Corporate Governance) }\end{array}$ & Human Governance Approach \\
\hline Governance Ethos & $\begin{array}{l}\text { - Emphasis on rules and } \\
\text { procedures } \\
\text { - Prevent wrongdoings. }\end{array}$ & $\begin{array}{l}\text { - Emphasis on values } \\
\text { - Promotes good conduct } \\
\text { - Individual trust promotes moral } \\
\text { and responsible behaviour. }\end{array}$ \\
\hline Nature of person & $\begin{array}{l}\text { - Individual is treated as a } \\
\text { complicated machine } \\
\text { (artificial person). }\end{array}$ & $\begin{array}{l}\text { - Individual is viewed as a natural } \\
\text { human. }\end{array}$ \\
\hline Definition of Ethics & $\begin{array}{l}\text { - A narrow definition of moral } \\
\text { or ethical behaviour. }\end{array}$ & $\begin{array}{l}\text { - A broad definition of moral or } \\
\text { ethical behaviour. }\end{array}$ \\
\hline Legal emphasis & $\begin{array}{l}\text { Obey the letter of the law } \\
\text { but not the intention of the } \\
\text { law. }\end{array}$ & $\begin{array}{l}\text { - Giving intention to the spirit of } \\
\text { the law. }\end{array}$ \\
\hline Diagnosis & $\begin{array}{l}\text { Diagnose unethical behaviour } \\
\text { problem by treating the } \\
\text { symptom. }\end{array}$ & $\begin{array}{l}\text { Diagnose unethical behaviour } \\
\text { problem by treating the root } \\
\text { cause. }\end{array}$ \\
\hline
\end{tabular}

Source: Adapted from Salleh and Ahmad (2008)

Due to the fact that human governance relies on principles or values, it currently becomes an internal mechanism that guides the human behaviour. Unlike corporate governance, the target object is not the corporation, but the soul of the corporation, which is the human being. Through the adoption of human governance, the stewards of corporations would be able to steer their corporations with integrity. Promoting the concept of human governance to be inculcated into ethics in accounting education can bring back the profoundness of governing the individual (human being) rather than the corporation (the artificial legal person).

\section{Human Governance's Ontological Stance}

To be a human, it is insufficient if one does not behave with conscience. Driven from the reality view of Quantum physics, human governance views everything as connected, from the smallest micro life to enormous galaxies. We are all ONE. But Oneness goes beyond not just the physical universe; it also includes all physical and nonphysical realities. If every person in the world could grasp the concept of oneness, there would be no more conflict and the world would be peaceful. By remembering this we can be more aware and help and forgive one another (connectedness). The concept of Human Governance also explains the contribution of self-accountability and self-awareness; which means even if we are not accountable or answerable to something, it does not allow us to practice something beyond the values of humanity. 


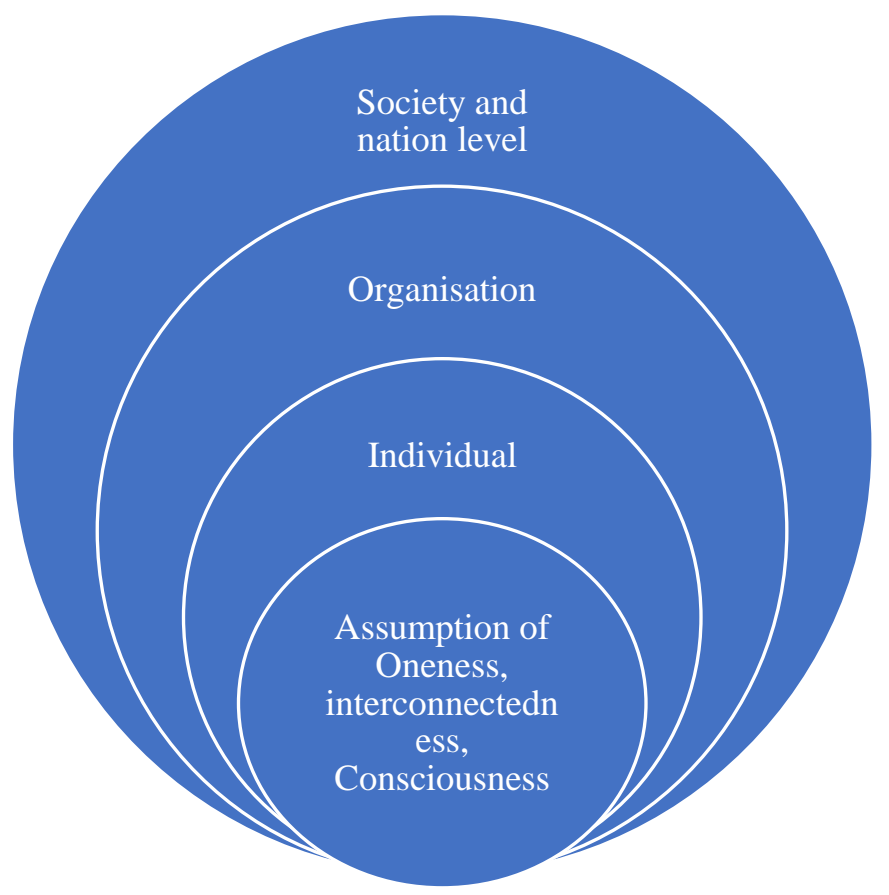

Figure 1- The concept of human governance

Consciousness is the state or quality of awareness or being aware of an external object or something within oneself. Despite the difficulty in definition, many philosophers believe that there is a broadly shared underlying intuition about what consciousness is. The dictionary meaning of the word consciousness extends through several centuries and associated cognate meanings which have ranged from formal definitions to somewhat more skeptical definitions. One formal definition indicating the range of these cognate meanings is given in Webster's Third New International Dictionary stating that consciousness is "awareness or perception of an inward psychological or spiritual fact: intuitively perceived knowledge of something in one's inner self".

Interconnectedness and oneness is part of the terminology of a worldview which sees an oneness in all things. A similar term, interdependence, is sometimes used instead, although there are slightly different connotations. Both terms tend to refer to the idea that all things are of a single underlying substance and reality, and that there is no true separation deeper than appearances. Some feel that 'interconnectedness' and similar terms are part of a contemporary lexicon of mysticism, which is based on the same core idea of universal oneness. The concept of human governance can be summarized as seen in Figure 1.

\section{Conclusion}

The debates on the inadequacies of existing ethics education in accounting curriculum have continued despite the changes made to update the curriculum. Given that rules-based is the foundation of ethics in accounting education, the existing ethics education system has been blamed as one of the causes leading to accounting frauds and unethical behaviours. There is a need to reframe and integrate ethics curriculum in accounting. The philosophies, theologies, and cultural 
difference should be considered when teaching ethics. Human governance offers a difference in term of objectives in teaching ethics and view on ethics. Consequently, the philosophy of teaching ethics needs to be revisit. Before embedding the concept of human governance in the accounting ethics education, accounting educators need to understand the concept, shift their view towards the reality of the world phenomena (ontological assumptions) including the definition of human and ethics. The concept of human governance needs to be introduced in workshops for educators from all levels of education to avoid misunderstanding and misinterpretation. The meaning of ethics needs to be revisited and the framework of teaching ethics in accounting education should be considered with using eastern philosophical framework instead of the current western philosophical framework by bringing in religion into education. The level of understanding and acceptance toward the concept of human governance needs to be investigated. The instillation of this concept into accounting ethics education will not become a reality without the cooperation from the Ministry of Higher Education and furthermore, to become a national agenda if it can be embedded in the Malaysia's National Philosophy of Education.

This paper provides new additional literature on the view of ethics based on human governance. Most of the current literature has been viewed based on earlier classical science which was rules based view of ethics. This is a departure from prior studies and therefore represents a new approach to ethics in accounting education. Human governance concepts require accounting educators to shift their mind-set from objective and quantitative obsession (rules based) to one that recognises the subjective world from the perspective of quantum science which is principle based or sometimes known as values based.

This paper views the epistemological and ontological stance of accounting educators in relation to how they perceive science and knowledge and the notion of reality. If educators today still believe in the current framework of educational setting which is established on a by rule-based structure, humans will still be viewed as machines and the degeneration of morality of the products (students) is expected, due to the absence of spirituality. The traditional education culture describes human behaviour using general laws. The generalisation of laws, which is said to operate anywhere, anytime, and on anyone, makes education to be non-scientific because of the absence of verifiability. On the other hand, human governance is principle-based and views the reality of the world as subjective and unpredictable. This view of epistemology and ontology is crucial in order to identify the level of readiness of educators to inculcate human governance through ethics in accounting education. The extended research of accounting ethics education to include more principles should be emphasized. Thus, policy makers should provide a platform to promote any innovative ideas such as using the human governance principle based approach to develop a holistic accounting education curriculum

\section{References}

Al-Attas, S. M. (1990). The Nature Of Man And The Psychology Of The Human Soul . Kuala Lumpur: International Institute Of Islamic Thought And Civilization (Istac).

Alavi, H. R. (2009). Ethical Views Of Ibn Miskawayh And Aquinas. Philosophical Papers And Review May, Vol. 1 (4), Pp. 001-005. 
INTERNATIONAL JOURNAL OF ACADEMIC RESEARCH IN BUSINESS AND SOCIAL SCIENCES

Vol. 9, No. 7, July, 2019, E-ISSN: 2222-6990 @ 2019 HRMARS

Amernic, J., \& Craig, R. (2004). Reform Of The Accounting Education In The Post-Enron Era: Moving Accounting 'Out Of The Shadows. Abacus, 342-78.

Amlie, T. T. (2010). Do As We Say, Not As We Do: Teaching Ethics In The Modern College Classroom. American Journal Of Business Education, 95-103.

Arjoon, S. (2005). Corporate Governance: An Ethical Perspective. Journal Of Business Ethics, 61, 343352.

Armstrong, M. B. (1993). Ethics And Professionalism In Accounting Education: A Sample Course. . Journal Of Accounting Education 11 (1), 77-92.

Becker, E. (2006). What Does It Mean To Be Human? Common Ground Journal, 3(2), 10-18.

Blanthorne, C., Kovar, S. E., \& Fisher, D. G. (2007). Accounting Educators' Opinions About Ethics In The Curriculum: An Extensive View. Issues In Accounting Education. Vol 22. No. 3, 355-390.

Boyce, G. (2008). The Social Relevance Of Ethics Education In Global(Ising) Era: From Invidual Dilemmas To Systemic Crises. Critical Perspectives On Accounting 19, 255-290.

Bunker, R. B., \& Casey, K. (2012). Faciliting Payment Versus Bribes: Are We Sending Conflicting Ethical Signals In Accounting Education? International Journal Of Business And Social Science, 47-50.

Clark, M., \& Leonard, S. (1998). Can Corporate Codes Of Ethics Influence Behavior? Journal Of Business Ethics, 17, 619-30.

Dellaportas, S., Kanapathippillah, S., Khan, A., \& Leung, P. (2014). Ethics Education In The Australian Accounting Curriculum: A Longitudinal Study Exam Ining Barriers And Enablers. Accounting Education : An International Journal, 362-382.

Fisher, D. G., \& Swanson, D. L. (2005). A Call To Strengthen Proposed Nasba Ethics Requirements: A Three Step Formula. Compliance \& Ethics, 2(3), 36-38.

Fisher, D. G., Swanson, D. L., \& J.Schmidt, J. (2011). Accounting Education Lags Cpe Ethics Requirements: Implications For The Profession And A Call To Action. Accounting Education: An International Journal, Vol. 16, No. 4, 345-365.

Geary, W. T., \& Sims, R. R. (1994). Can Ethics Be Learned? Accoungting Education 3 (1), 3-18.

Ghaffari, F., Kyriacou, O., \& Brennan, R. (2008). Exploring The Implementation Of Ethics In U.K. Accounting Programs. Issues In Accounting Education, Vol.23, No. 2, 183-198.

Gioia, D. A. ( 2002). Business Education's Role In The Crisis Of Corporate Confidence. Academy Of Management Executive 16(3) , 142-144.

Gray, R., Bebbington, J., \& Mcphail, K. (1994). Teaching Ethics In Accounting And The Ethics Of Accounting Teaching: Educating For Immorality And A Possible Case For Social And Environmental Accounting Education. Accounting Education 3 (1), 51-75.

Hansen, J. C. (2010. ). Where Were The Auditors? Using Aaers In Introductory Or Advanced Auditing Courses. Journal Of Accounting Education, 28(2): 114-127.

Healy, M., \& Iles, J. (2002 ). The Establishment And Enforcement Of Codes. Journal Of Business Ethics, 117-124.

Helin, S., \& Sandstro"M:, J. (2007). An Inquiry Into The Study Of Corporate Codes Of Ethics. Journal Of Business Ethics 75, 253-271.

Hilgenheger, N. (1994). Johann Friedrich Herbart. Prospects: The Quarterly Review Of Comparative Education, Vol. Xxiii, No. 3/4, P. 649-664. 
INTERNATIONAL JOURNAL OF ACADEMIC RESEARCH IN BUSINESS AND SOCIAL SCIENCES

Vol. 9, No. 7, July, 2019, E-ISSN: 2222-6990 @ 2019 HRMARS

Ifac. (2006). les 4 Professional Values, Ethics And Attitudes. Retrieved August 24, 2008, From Ifac: Http://Www.Ifac.Org

Ifac. (2008). Introduction To International Education Standards. Retrieved September 25, 2009, From Ifac: Http://Www.Ifac.Org.

Kaptein, M., \& Schwartz, M. S. (2008). The Effectivenessof Business Codes: A Critical Examination Of Existing Studies And The Development Of An Integrated Research Model. Journal Of Business Ethics 77, 111-127.

Kretzmann, N., \& Stump, E. (1998). Aquinas, Thomas. In Routledge Encyclopedia Of Philosophy. London And New York: Routledge.

Loeb, S. (1988). Teaching Students Accounting Ethics: Some Crucial Issues. Issues In Accounting Education 3 (Fall), 316-329.

Low, M., Davey, H., \& Hooper, K. (2008). Accounting Scandals, Ethical Dilemmas And Educational Challenges. Critical Perspectives On Accounting 19, 222-254.

Marnburg, E. (2000). The Behavioral Effects Of Corporate Ethical Codes: Empirical Findings And Discussion,. Business Ethics: A European Review, 9, 200-10.

Mcdonald, G. M., \& Donleavy, G. D. (1995). Objective To The Teaching Of Business Ethics. Journal Of Business Ethics 14(10), 839-853.

Mcevoy, J. (2006). Ultimate Goods: Happiness, Friendship, And Bliss. In A. Mcgrade, The Cambridge Campanion To Madieval Philosophy (Pp. 254-275). Cambridge:: Cambridge University Press.

Mcphail, K. (2001). The Other Objective Of Ethics Education: Re-Humanising The Accounting Profession- A Study Of Ethics Education In Law, Engineering, Medicine And Accountancy. Journal Of Business Ethics, 279-298.

Mcphail, K. (2006). Ethics And The Individual Professional Accountant: A Literature Review. Retrieved March 13, 2012, From The Institute Of Chartered Accountants Of Scotland:

Http://Www.Icas.Org.Uk/Researchpublications

Mohammad, A., Maisarah, M., \& Ainun, A. (2002). Ethics And The Accounting Profession In Malaysia. The Asian Academic Accounting Associationconference. Nagoya Japan.

Mohammed, A. (2005 ). The Relationship Between Islamic Rules And Accountants' Ethics. Unpublished Manuscript. Yemen: Hadhramout. .

Mohe. (2007). Hala Tuju 2 -Reassessment Report On Accounting Programme At Public Universities Of Malaysia 2006. Shah Alam: Pusat Penerbitan Universiti (Upena).

Ozmon, H. A., \& Craver, S. M. (2008). Philosophical Foundation Of Education. New Jersey: Pearson Merrill/Prentice Hall.

Palmer, P. J. (2007). The Courage To Teach: Exploring The Inner Landscape Of A Teacher's Life. San Francisco: John Wiley \& Sons.

Piper, T. R., Gentile, M. C., \& Parks, S. D. (1993). Can ,Ethics Be Taught? Perspectives, Challenges, And Approaches At Harvard Business School . Harvard Business School.

Plimmer, G. (2002). Can Schools Teach Morality? The Lessons Of Enron. London (Uk): Financial Times. Ryack, K. N., Mastilak, M. C., Hodgdon, C. D., \& Allen, J. S. (2015). Concept-Based Education In RulesBased World: A Challenge For Accounting Educators. Issues In Accounting Education, 251.

Salleh, A., \& Ahmad, A. (2008). Human Governance. Petaling Jaya: Mph Publishing. 
Salleh, A., \& Ahmad, A. (2009). Re-Actualizing The Leadership Of Professional Accountants In Business:The New Sciences And Human Governance Way. Kuala Lumpur: Mia.

Salleh, A., \& Ahmad, A. (2010). Human Governance: Bringing The Meaning Of Integrity In Life Of Professional Accountants. Malaysia: Malaysia Institute Of Accountant (Mia).

Salleh, A., \& Ahmad, A. (2012). A Scientific Worldview Of Accounting Ethics And Governance Education: The Right Footing Of International Education Standard 4. Asian Academy Of Management Journal, 131-149.

Stoddart, W. (1985). The Role Of Culture In Education. Studies In Comparative Religion, Vol. 11, No. $1 \& 2$.

Swanson, D., \& Frederick, W. (2003). Are Business Schools Silent Partners In Corporate Crime? Journal of Corporate Citizenship 9, 24-27.

The New International Webster's Comprehensive Dictionary Of The English Language. . (1996). Naples, Fl: Trident Press International.

Visher, G. S. (1997). Human Values. New York: Nova Science Publishers. 